\title{
EQUIVALENT WIND FARM POWER CURVE ESTIMATION*
}

\author{
Maja Celeska, Krste Najdenkoski, Vladimir Dimčev, Vlatko Stoilkov \\ Faculty of Electrical Engineering and Information Technologies, \\ "Ss. Cyril and Methodius" University in Skopje, \\ Rugjer Bošković bb, P.O. box 574, 1001 Skopje, Republic of Macedonia \\ celeska@feit.ukim.edu.mk
}

\begin{abstract}
A b s t r a c t: Wind turbine manufacturers publish and certify power curves for their turbines. These turbine power curves are used for planning purposes and estimating total wind power production. When a wind plant consisting of many turbines connects to the utility grid and starts operation, the focus shifts to the entire plant's performance. An equivalent wind plant power-curve becomes highly desirable and useful in predicting plant output for a given wind forecast. For the purposes of this paper detailed data have been collected from a wind power plant to develop such an equivalent power curve. The method is evaluated using data from operational wind farms and the methods are compared to a modified IEC 61400-12 bin method. This paper will summarize available data, methodology, discuss the validation process and explore the applicability of such an approach on other wind power plants without detailed data.
\end{abstract}

Key words: wind energy; power curve; power performance; bin method

\section{ПРОЦЕНА НА СЕВКУПНАТА КРИВА НА МОК̈НОСТ НА ЕДНО ВЕТЕРНО ПОЛЕ}

А п с т р а к т: Производителите на ветерни турбини со сигурност гарантираат за точноста на кривите на моќност за нивните турбини. Според соодветната крива на моќност се изготвуваат процени за вкупното производство на електрична енергија од едно ветерно поле. Откако ветерното поле ќе се поврзе на мрежа и ќе започне со работа, од интерес се севкупните карактеристики за оцена на неговата работа. Изготвувањето на севкупна крива на моќност е многу полезно при планирањето на работата на ветерното поле при познати ветерни режими на конкретната локација. За потребите на овој труд се користени детални мерни податоци од едно ветерно поле, за методолошки да се изработи една севкупна крива на моќност. Точноста на методот е потврдена со споредба на податоците обработени според бин-методот, претставен во стандардот IEC 61400-12. Во трудот сумарно се претставени обработените податоци, методите за изработка на еквивалентната крива на моќност, испитана е валидноста на предложениот модел и истражена е неговата применливост за други ветерни полиња при недостиг на детални податоци.

Клучни зборови: енергија од ветерот; крива на моќност; приказ на искористливост; бин-метод

\section{INTRODUCTION}

Wind turbine manufacturers publish and certify power curves for their turbines. These turbine power curves are used for planning purposes and estimating total wind power production. When a wind plant consisting of many turbines connects to the utility grid and starts operation, the focus shifts to the entire plant's performance. An equivalent wind plant power-curve becomes highly desirable and useful in predicting plant output for a given wind forecast. An equivalent power curve for the entire plant can serve the same purpose for plant and system operators to predict the plant output for a given wind speed. However, unlike the single turbine power curve, a single curve cannot capture all the nuances of a wind plant consisting of tens or even hundreds of turbines. A model consisting of a set of power curves is required to fully characterize the complex input/output relationship of a wind plant to

\footnotetext{
* Extended version of the manuscript published in the Proceedings of the $10^{\text {th }}$ MAKO CIGRE Conference, Ohrid, September $24-26,2017$ (Проширена верзија од трудот објавен во Зборникот на трудови од 10. Советување на МАКО СИГРЕ, Охрид, 24-26 септември 2017).
} 
account for the effects of different wind directions, local terrain, and asymmetric turbine layout in a wind plant. In this paper, the data are obtained from the Wind Power Plant (WPP) Bogdanci, for the development of such a model. The data include plant output, wind speed and direction from meteorological towers, and nacelle anemometer readings and power output from each turbine. From this extensive dataset, the distributions of wind speed and power production of all turbines are analyzed over a wide range of wind speeds. From these distributions, a model is constructed to generate an equivalent power curve for the plant.

\section{GENERAL DATA FOR WPP BOGDANCI}

Performance of a single wind turbine can be characterized by a power curve - a graphical representation of the turbine electric power output as a function of the hub-height wind speed. With such a curve, the turbine power output and energy production can be predicted without detailed knowledge of a turbine and its components. Turbine manufacturers provide measured power curves for turbines based on industry standard IEC 61400-12-1.1. Figure 1 below is an example of a power curve of a wind turbine with active power control. The wind power plant analyzed for this report is located in south-east part of the Republic of Macedonia. It consists of 16 turbines from the same type - SIEMENS SWT-2,3-93 (80 $\mathrm{m}$ hub height). The power plant covers a total area of approx. 10 ha although only approx. 4 ha are used permanently for the operation of the wind farm (equivalent to $40 \%$ of the total area of the site). The standard voltage level for the internal cabling of wind parks is $20 \mathrm{kV}$. Each turbine has its own $0.69 / 20 \mathrm{kV}$ transformer. The produced energy is transmitted through $110 / 20 \mathrm{kV}$ substation with two 31.5 MVA transformers. There are two meteorological (MET) towers at this site [2]. Figure 2 is a site map of the WPP Bogdanci.

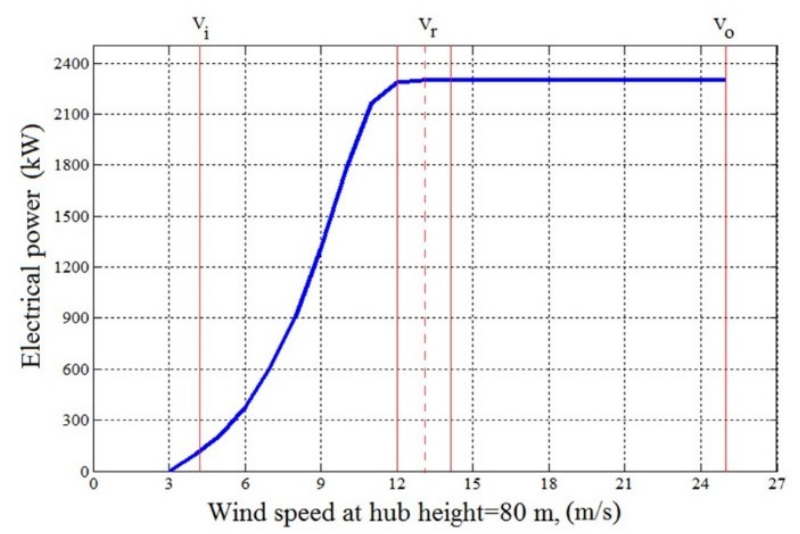

Fig. 1. Turbine power curve [1]

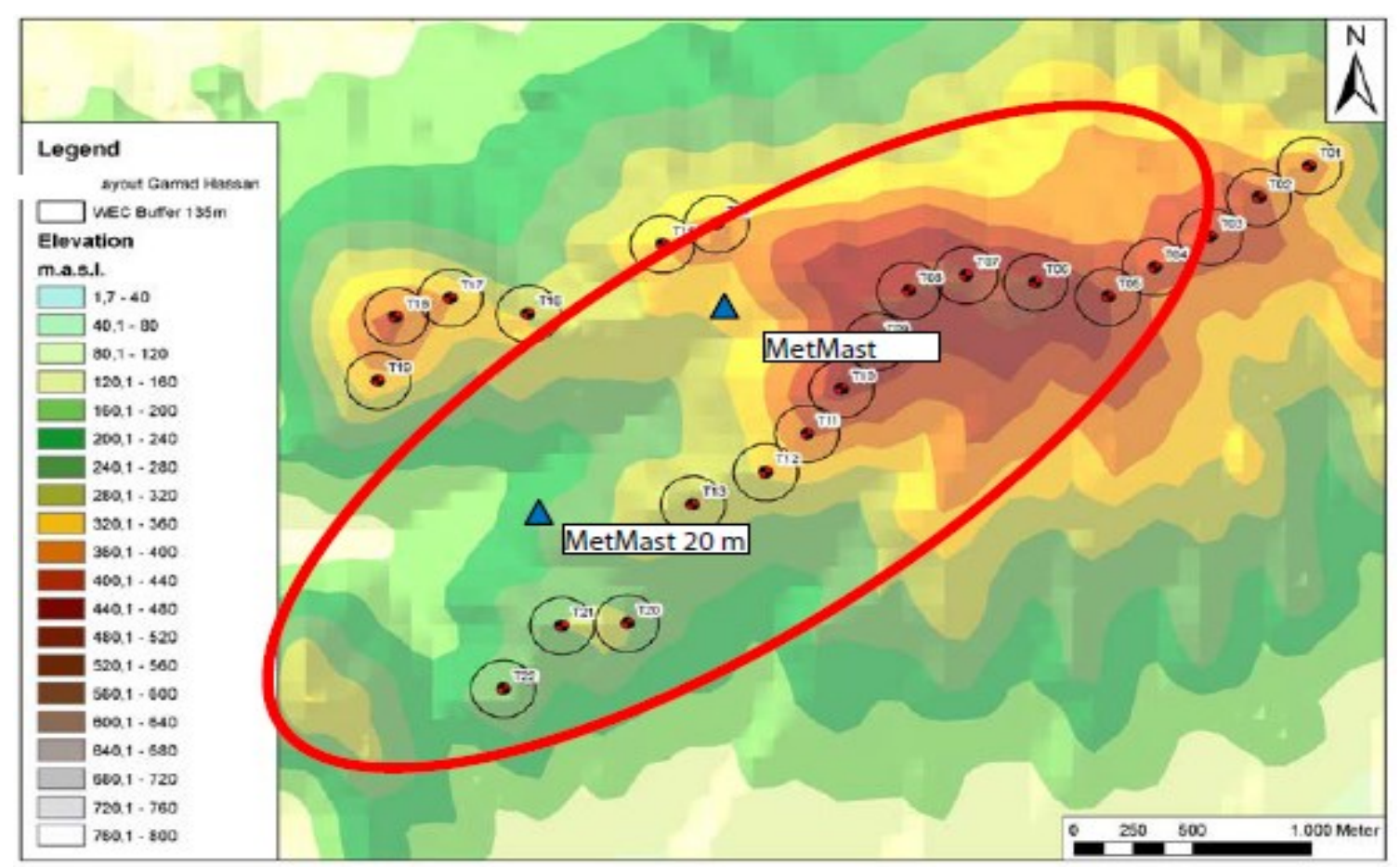

Fig. 2. Turbine and MET tower locations (phase 1 and phase 2) [2] 
The wind park area covers elevations of between 280 and $500 \mathrm{~m}$ above sea level. The longterm average wind speed at an elevation of $500 \mathrm{~m}$ has been established as $6.9 \mathrm{~m} / \mathrm{s}$ at $50 \mathrm{~m}$ above ground. The turbines are generally lined up in rows which are perpendicular to the prevailing wind direction (north-west) at the site. The average distance between turbines in the same row is roughly 2.2 rotor diameters. The two MET towers measure wind speed (in $\mathrm{m} / \mathrm{s}$ ) and direction (from $0^{\circ}$ to $359^{\circ}$ ) at $50 \mathrm{~m}$. In addition, barometric pressure (in $\mathrm{mb}$ ) and temperature (in ${ }^{\circ} \mathrm{C}$ ) are measured at both MET towers.

\section{AVAILABLE DATA AND DATA QUALITY ISSUES}

The utility has installed a Plant Information (PI) system to collect detailed operating information of the wind plant. For each turbine, the collected data includes turbine status: rotor speed (rpm), power output $(\mathrm{kW})$, nacelle position (degree), blade position (degree), yaw position, humidity and wind speed from the anemometer on top of the nacelle $(\mathrm{m} / \mathrm{s})$. The output of the entire plant is monitored by the utility's supervisory control and data acquisition (SCADA) system and transmitted to its PI system. Together with wind speed, direction, barometric pressure, and temperature data from the two MET towers and with other diagnostic information of the plant, there hundreds of thousands of data streams from the wind plant being collected and stored.

For turbine power curve measurements, the IEC standard recommends averaging the data over 10-minute periods. Following the IEC standard recommendation, all data from the PI system except for the individual turbine status data were averaged over 10-minute periods with the corresponding time stamps attached [3]. Because the raw PI data streams are not evenly spaced (i.e., the data are not stored in any fixed time intervals), one turbine availability status reading every 10 minutes may not represent the true turbine status during the entire 10 minutes. A turbine could be down at the beginning of the 10-minute period and returned to operation in the next minute (or vice versa), but the turbine availability status reading taken at the beginning would show the turbine was down (or up) for the entire 10minute period. Probably, that is the reason why there are small discrepancies between the produced and calculated energy from a single turbine.
Many of the observed outliers in the initial database, are due to problems with the MET tower anemometers, while other outliers may not be an error. For example, the turbines may not experience the same wind conditions as indicated by the MET tower readings. Turbine availability status data also have data quality issues. If a turbine is producing power with an availability status of 0 , there is obviously a conflict. However, the opposite condition of no power from a turbine with an availability status of 1 (and above cut-in wind speed at the hub height) is difficult to validate. Validity of other situations such as a rapid change in total numbers of available turbines in consecutive 10-minute periods is also harder to determine. However, a more rigorous quality check on the data was needed to address these issues. The first step was to remove data points that are considered as outliers form the power output of the 16 turbines available for generation. This is a somewhat arbitrary criterion and the remaining data have less than $1 \%$ uncertainty in output power. This step removed $9 \%$ of the points from the data stream.

\section{METHOD OF BINS}

The most straightforward approach is curve fitting. Another approach is to use the method of the bins specified in IEC 61400-12-1. Basically, this method uses measured 10-minute average wind speeds (at the hub height) and plant output power. The 10-minute average wind speeds are separated into $0.5 \mathrm{~m} / \mathrm{s}$ contiguous bins centered on multiplies of $0.5 \mathrm{~m} / \mathrm{s}(1.0 \mathrm{~m} / \mathrm{s}, 1.5 \mathrm{~m} / \mathrm{s}, 2.0 \mathrm{~m} / \mathrm{s}$, etc.). The mean value of power for each $0.5 \mathrm{~m} / \mathrm{s}$ bin is then calculated and plotted against the mean wind speed of each bin. The data shown in Figure 3 are normalized data power output from each turbine, for 2015 year.

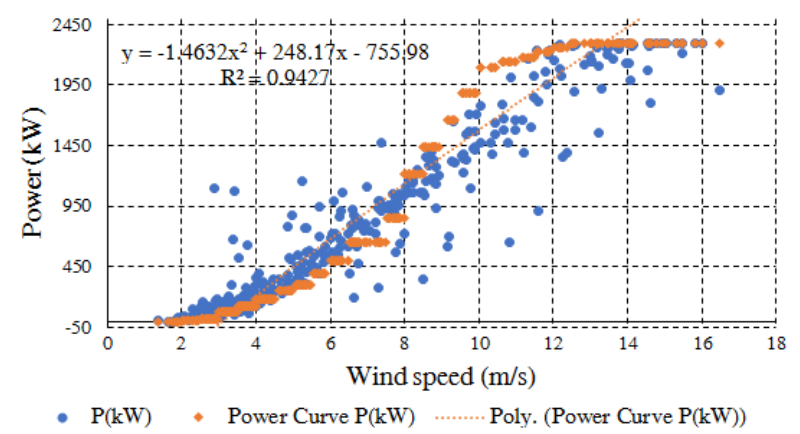

Fig. 3. Scatter plot of measured power output and assumed power output by the prescribed power curve 
It is clear that the relationship between wind speed and power output is not linear. If the bin characterized by wind speeds between 5 and 5.5 is observed, and a cubic relationship between the different variables is assumed, the theoretical power output associated with the wind speed at the maximum value of the bin is $33.1 \%$ higher than that associated with the wind speed at the minimum value of the bin. To take into account the "nonlinear" relationship between the wind speed and the power, a new method of obtaining the $V_{i}$ and $P_{i}$ values is proposed:

$$
\begin{gathered}
V_{i}=\frac{V_{i, H}-\mathrm{V}_{i, L}}{2} \\
P_{i}=\frac{1}{N_{i}} \sum_{j=1}^{N_{i}} \frac{P_{n, i, j} \cdot V_{n, i, j}^{k}}{V_{i}^{k}}
\end{gathered}
$$

where:

$V_{i, H}$ - is the maximum value of wind speed in bin $i$, $V_{i, L}$ - is the minimum value of wind speed in bin $i$,

$k-$ is a factor that must be adjusted for each direction sector and each wind speed bin.

To get the theoretical power that corresponds to any wind speed $(V)$ the following steps must be followed:

i) Select the bin that corresponds to the wind speed chosen.

ii) Apply the following equation, in order to consider the relationship shown in equation 2 .

$$
P_{V}=\frac{P_{i} \cdot V^{k}}{V_{i}^{k}}
$$

where: $\checkmark$,

$P_{v}-$ is the theoretical power corresponding to

$V_{i}-$ is the normalized and averaged wind speed in bin $i$,

$P_{i}-$ is the normalized and averaged power output in bin $i$.

To get the characterization some $k$ values have been tested from 0.5 to 3, in steps of 0.5. Each bin has been characterized for the $k$ value that optimizes the mean squared error, obviously the data taken to calculate the error are only those that belongs to this bin [3-6].

To get the characterization some $k$ values have been tested from 0.5 to 3 , in steps of 0.5 . Each bin has been characterized for the $k$ value that optimizes the mean squared error, obviously the data taken to calculate the error are only those that belongs to this bin [3-6].

Figure 4 shows the distribution of wind direction at this wind plant as measured by wind vanes on the MET tower. The prevailing wind direction during the period when data are available is northwest (between $293^{\circ}$ and $338^{\circ}$ ). Wind blows from this sector more than $25 \%$ of the time-noticing the usable values of the wind speed, above $4 \mathrm{~m} / \mathrm{s}$.

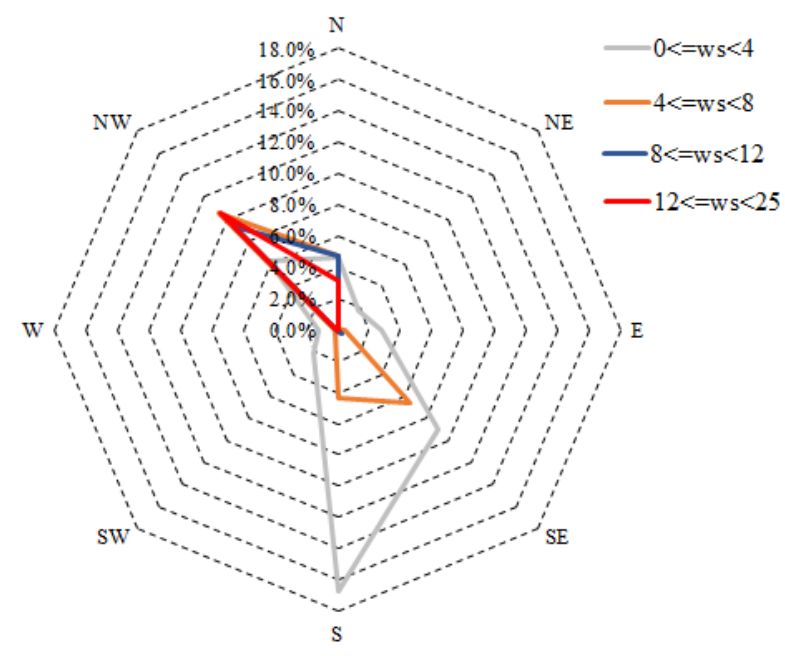

Fig. 4. Wind roes diagram

\section{THE ENERGY MODEL}

To estimate the energy generated by the turbine at a given site over a period, the power characteristics of the turbine are to be integrated with the probabilities of different wind velocities expected at the site.

The power curve of a wind turbine has three clearly defined parts (Figures 1 and 3). Firstly, between $0 \mathrm{~m} / \mathrm{s}$ and the cut-in wind speed $(4 \mathrm{~m} / \mathrm{s})$ the production is zero, then the power output increases following a cubic relationship with wind speed until the rated wind speed $(11 \mathrm{~m} / \mathrm{s})$, and finally, the power output is regulated to stay almost constant until the cut-out or furling wind speed $(25 \mathrm{~m} / \mathrm{s})$. This threepart shape suggests that different polynomial relationships should be used for different wind speed ranges. In this case, a linear regression is used to define the whole power curve of the power plant (Figure 3).

In the wind regime, the fraction of energy contributed by any wind velocity $V$ is the product of power corresponding to $V$ in the power curve, that 
is $P(V)$ and the probability of $V$ in the probability density curve, which is $f(V)[4,5]$. Thus, at this site, the total energy generated by the turbine $E$, over a period $T$, can be estimated by:

$$
E=T \int_{v_{i}}^{v_{o}} P_{v} f(V) d V
$$

The power curve has two distinct productive regions - from $V_{\mathrm{I}}$ to $V_{R}$ and from $V_{R}$ to $V_{O}$. Thus, it can be written:

$$
E=E_{I R}+E_{R O},
$$

where $E_{I R}$ and $E_{R O}$ are the energy yield corresponding to $V_{I}$ to $V_{R}$ and $V_{R}$ to $V_{O}$, respectively. From the foregoing discussions, it can be written:

$$
E_{I R}=T \int_{v_{I i}}^{v_{R}} P_{v} f(V) d V
$$

and

$$
E_{R O}=T P_{R} \int_{v_{R}}^{v_{O}} f(V) d V .
$$

Taking into account the relations for wind velocity and Weibull probability density function, the next relation for the produced energy from each turbine can be derived:

$$
\begin{aligned}
& E_{I R}=T P_{R} \int_{v_{I}}^{v_{R}}\left[\frac{V^{n}-V_{I}^{n}}{V_{R}^{n}-V_{I}^{n}}\right] \frac{k}{c}\left(\frac{V}{c}\right)^{k-1} e^{-(V / c)^{k}} d V= \\
& =\left(\frac{T P_{R}}{V_{R}^{n}-V_{I}^{n}}\right) \int_{V_{I}}^{V_{R}}\left(V^{n}-V_{I}^{n}\right) \frac{k}{c}\left(\frac{V}{c}\right)^{k-1} e^{-(V / c)^{k}} d V .
\end{aligned}
$$

For simplifying the above expression and bringing it to a resolvable form, let us introduce the variable $X$ such that:

$$
X=\left(\frac{V}{c}\right)^{k}
$$

Then:

$$
d X=\frac{k}{c}\left(\frac{V}{c}\right)^{k-1} \text { and } V=c X .
$$

With equation 9 it can be written:

$$
X_{I}=\left(\frac{V_{I}}{c}\right)^{k}, X_{R}=\left(\frac{V_{R}}{c}\right)^{k} \text { and } X_{O}=\left(\frac{V_{O}}{c}\right)^{k}
$$

With this substitution, and simplification thereafter, EIR can be expressed as:

$$
\begin{aligned}
E_{I R}= & \frac{T P_{R} c^{n}}{V_{R}^{n}-V_{I}^{n}} X^{n / k} e^{-X} d X- \\
& -\frac{T P_{R} V_{I}^{n}}{V_{R}^{n}-V_{I}^{n}}\left[e^{-X_{I}}-e^{-X_{R}}\right] \\
E_{R O}= & T P_{R} \int_{v_{R i}}^{v_{O}} \frac{k}{c}\left(\frac{V}{c}\right)^{k-1} e^{-(V / s)^{k}} d V \\
= & T P_{R}\left(e^{-X_{R}}-e^{-X_{O}}\right) .
\end{aligned}
$$

The above expressions can be evaluated numerically [5]. The capacity factor CF - which is the ratio of the energy actually produced by the turbine to the energy that could has been produced by it, if the machine would has operated at its rated power throughout the time period - is given by:

$$
C F=\frac{E}{P_{R} T}=\frac{E_{I R}+E_{R O}}{P_{R} T},
$$

Thus:

$$
\begin{gathered}
C F=\frac{c^{n}}{V_{R}^{n}-V_{I}^{n}} \int_{X_{I}}^{X_{R}} X^{n / k} e^{-X} d X- \\
-\frac{V_{I}^{n}}{V_{R}^{n}-V_{I}^{n}}\left[e^{-X_{I}}-e^{-X_{R}}\right]+\left(e^{-X_{R}}-e^{-X_{O}}\right) .
\end{gathered}
$$

The energy model discussed above is validated with the field performance of a $2.3 \mathrm{MW}$ wind turbine in Figure 5. The turbine considered here has cut-in, rated and cut-out wind speeds of 3, 11 and 25 $\mathrm{m} / \mathrm{s}$ respectively. From the manufacturer's power curve, the velocity-power proportionality for the design was found to be 2.16 . It can be observed that the predicted performance closely follows the measured values throughout the period.

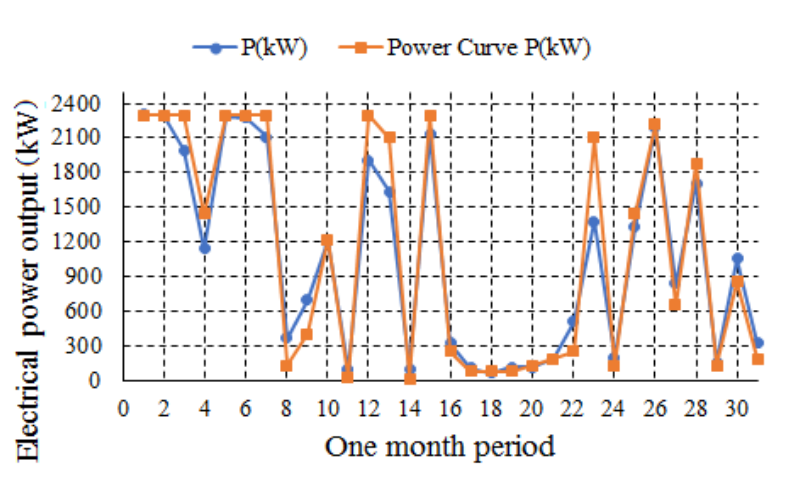

Fig. 5. Estimated and measured power output 


\section{EQUIVALENT PLANT POWER CURVE}

A single turbine power curve is determined by measuring the turbine output and inflow wind speed at the hub height. The location of wind measurement relative to the turbine is specified in IEC 61400-12-1. For an entire plant, there is no specification to determine a single representative wind speed that can characterize the wind condition of the plant $[7,8]$. The scatter plots of wind plant output in Figure 3 suggest wind speed readings from either MET tower can be used to construct an equivalent power curve for the plant. The advantage of using the metered output of the entire plant to construct an equivalent power curve is that both array losses (due to wake effects) and electric collecting system losses are automatically included. The data are mathematically reorganized so that in a simple way it will lead to a conclusion. The method of bins, above mentioned, is applied and the most straightforward approach-curve fitting.

The results of these two approaches using wind speeds of MET tower are shown in Figure 6. It can be seen that these two approaches produce similar results. The jagged appearance of the method of the bins curve at rated wind speeds manifests the challenge of modeling the wind power plant. After filtering the data $100 \%$ of wind speed distribution is included in the range of $1.5-16.5 \mathrm{~m} / \mathrm{s}$. That is why the whole range of wind speeds available for the turbines can't be validated. On the other hand, this coincidence almost completely fits with the flat portion of the curve fitting trace. Since the curve fitting if from the third order polynomial curve, after 15 $\mathrm{m} / \mathrm{s}$ it starts bending downward beyond the inflection.

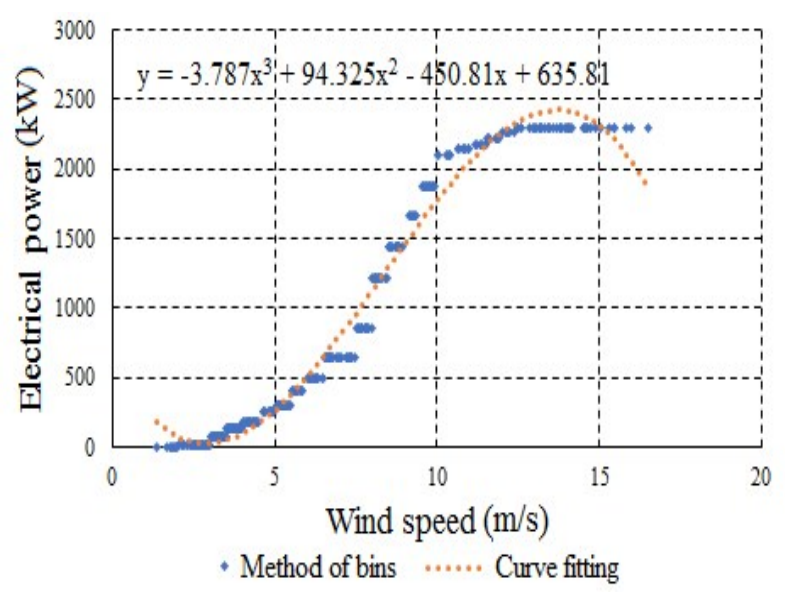

Fig. 6. Equivalent wind plant power curves
The equivalent power curve can be used to predict plant output that is close to the measured value [8]. Using 10-minute average metered power and MET tower wind speeds, these two equivalent power curves yield mean absolute errors (MAE) of 2.910 MW (method of bins) and 3.312 MW (curve fitting), about $9 \%$ of the plant installed capacity. This is an expected outcome because data used to derive the equivalent power curves contain a wide range of power levels for any given wind speed value (Fig. 3).

\section{CONCLUSION}

Characterization of the wind turbine power curves in relation to the wind speed recorded at a meteorological mast that may be situated some distance from the turbine is a challenging problem that must be solved in order to optimize the operation and maintenance of the wind farm.

Many wind speed values are required to characterize the plant operation. This point is clear by the wide spread of the wind plant output at any given wind speed shown in the scatter plots in this report. Depending on how the wind speed values are obtained, using them to characterize the plant operation can result in large uncertainty. There are other variables besides wind speed that affect the plant performance and output levels. The results of directionally equivalent power curves demonstrated that separating the wind resource into major sectors marginally improves the representation. More data are required to reduce the noise in the resulting equivalent power curves. Finer wind sectors may incrementally improve the accuracy further, but also incurs the problem of determining the wind directions that are representative of the wind conditions for the entire wind plant.

The direct estimate approach requires the most amounts of input data, and produces the best results compared to other approaches tested. This approach is straightforward and the concept behind it is simple.

However, its success depends on finding the average wind speed of the entire wind field in a wind power plant, when it comes to method applicability over different wind power plants. At the wind plant, it turns out that average values of all nacelle anemometer readings provide very accurate estimates of the wind conditions for the entire wind plant. This method neglects the wind direction and yaw errors. It assumed that wind turbines will be 
turned into the wind within 10 minutes and the errors of neglecting wind direction and yaw errors are small compared to other uncertainties. If the average wind speed at a wind plant can be forecast with other methods or numerical models, the direct estimate approach can predict the plant output accurately, provided the numbers of online turbine are known in advance.

The direct estimate method should be very useful in practice because only one wind speed data stream (along with temperature and barometric pressure information to calculate air density values for further adjustment, if necessary) and numbers of turbines online are needed to estimate the plant output. For wind plants without reliable MET tower data streams, it is the only way to estimate plant output, and can produce very useful results.

\section{REFERENCES}

[1] SIEMENS, SWT - 2.3 - 113 Turning moderate wind into maximum results, Answers for energy, 2011.
[2] Macedonian Power Plants, "Park of wind power plants pilot project", Skopje 2012.

[3] EN 61400-12-1: Wind turbines - Part 12-1: Power performance of electricity producing wind turbines, 2010.

[4] Llombart, A., Watson, S. J., Llombart1, D., Fandos. J. M. Power Curve Characterization. I: Improving the Bin Method. DOI: 10.24084/repqj03.304, March, 2010.

[5] Sathyajith, M., Geetha Susan Philip, Chee Ming Lim: Analysis of Wind Regimes and Performance of Wind Turbines. Advances in Wind Energy Conversion Technology, Environmental Science and Engineering. DOI: 10.1007/978-3-540-88258-9_2, Springer, 2011.

[6] Llombart, A., Watson, S. J., Fandos, J. M., Llombart. D.: Power Curve Characterization. II: Modelling Using Polynomial Regression. RE\&PQJ, Vol. 1, No. 3, 363-366, March 2011.

[7] Smith, B.. Link, H., Randall, G.- Applicability of nacelle anemometer measurements for use in turbine power performance tests. Proceedings of the AWEA WINDPOWER 2002 Conference, Portland, OR, 2-5 June 2002.

[8] Pedersen, T. F., Gjerding, S., Ingham, P., Enevoldsen, P., Hansen, J. K., Jørgensen, H. K.: Wind Turbine Power Performance Verification in Complex Terrain and Wind Farms - Risø-R-1330(EN), Risø National Laboratory, Roskilde, April 2002. 
